\title{
Sports Idioms and Their Interpretation in Different Dimensions
}

\author{
Gevorg Barseghyan \\ Yerevan State University
}

\begin{abstract}
The present paper aims at elucidating the ethnocultural relevance of sports terms and expressions which tend to penetrate into everyday English speech as well as political discourse. Obvious is the fact that the character and essence of cross-cultural interrelations depends, to a great extent on the participants' ability to understand each other in order to reach an agreement. It is also well known that mutual understanding is in most cases defined by the ethnic culture of each side and the psychology of the ethnic group. Members of common culture not only share the same information but also the methods of coding, storing and retrieving the information. Rituals, traditions, customs are very closely connected with language and form part and parcel of the linguacultural "realia". In the present article sports terms and expressions are viewed as realia and social behaviour patterns as each nation has its unique way of understanding and perceiving a game in its own way, thus attaching some symbolic significance to it understandable within the scope of the linguocultural traditions of the country it has originated in.

Our observations show that the wide use of sports terms and expressions in non-sporting situations, particularly in political discourse and everyday speech is to a certain extent conditioned by their sociocultural origin and the new connotational meanings acquired in the course of the language development.
\end{abstract}

Key words: sports terms and idioms, expression of one's identity, nonsporting situations, sociocultural nature of sports idioms, linguocultural realia, hidden codes, code breaker, popular consciousness, international communication.

\section{Introduction}

In recent years extensive research in Communicative Language Teaching served as theoretical and methodological basis for the emergence of several 
approaches, the ethnographic approach (Hymes 1974); and the sociocultural one in particular (Saphonova 1991) that aimed to co-teach language and culture (Vereschagin, Kostomarov 1990); the core of which is the dialectical connection between language and culture. Language is a means of expression of one's identity. It is impossible to understand a foreign language unless you at least have some idea about the conditions the nation speaking the language lives in. In other words, real use of linguistic elements in speech and real speech productivity are conditioned by the knowledge of the social-cultural life of the people speaking the language. Rituals, traditions, customs are very closely connected with language, as they form part and parcel of linguocultural realia (Edward 1990); British sports idioms, for example, known to express everything that concerns mankind, mediating the joy and misery of life, sorrow, and happiness, honor and shame, rising to greatness and falling into objection, in fact, indicate elements of British culture.

\section{Sports Idioms in Non-Sporting Situations}

In this paper an attempt is made to show that games and sports terms and expressions also belong here and constitute an important part of a nation's linguoculture. The target of the research is the study of sports idioms, their origin, their occurrence in the English language, the new connotational meanings they acquire in the course of language development, and their usage in the non-sporting situations and dimensions. The interpretation of the material scrupulously selected and presented in the paper enables us to reveal the typically British sociocultural nature of sports idioms and their ability to be well fit in non-sporting situations and everyday speech.

The purpose of this paper is also to go over one of the problems of ethnocultural studies, namely take into consideration sport and sports terms viewing them as realia and social behavior patterns closely linked to national character. The implicit significance of the question is elucidated through linguistic material.

In fact, each nation has its own way of seeing and doing things, based on written rules, and these hidden differences often make cooperation difficult. Members of common culture not only share the same information, but also methods of coding, storing and retrieving the information. These methods vary from culture to culture. 
In this paper we are concerned with the sports idioms which are used to appear in non-sporting situations. Thus if we do not know the rules and the origin of a given game we would be unable to understand the meaning of the verbal manifestation of the principles of the game, and the expressiveemotional-evaluative overtones they have acquired in different linguocultural contexts. We proceed from the fact that in the English language, and in the world of English reality, sports and, thus sports terms and expressions are part of the given cultural reality (Beard 1998).

The popular expression that's not cricket, for example, implies that someone has behaved badly. The term derives from the game of cricket. Cricket means fair and honorable behavior. When one is fair and honorable, one is cricket. You can say "You are cricket" to someone you respect, or "I'm cricket" about yourself. "I'm cricket" When you are cricket, you benefit yourself by avoiding your bad behaviours. On the other hand, you honor yourself. And that's really cricket.

Cricket is one of the ethnic values which is idiomatically used in other spheres of life, and its significance is ascribed to the universal concept of fair vs unfair. It is not cricket means it is not fair. We should hasten to add that the rules of this British game are very strict and fair. If an Englishman tells an Armenian "You are not cricket" the latter will not be able to understand it if he has no background knowledge about the English game of cricket. In order to understand what a foreigner wants to say by this or that phrase or even behaviour one should have some background information about the nation and its culture. Moreover, he must be familiar with certain British ethnocultural realias. The phrase it's not cricket became inexorably linked to the lack of honesty, integrity, morality or patriotism.

The goal of the paper (the study of sports idioms used in non-sporting dimensions), accounts for our interest in various researches on idiomatic expressions at large, the investigation and critical analysis of which disposes us to think that sports terms and expressions may well fit for non-sporting spheres and situations. Politics is one of those spheres. For example, to throw one's hat in the ring which is now actively used in political campaigns, when the politician announces his determination of becoming a candidate, comes from the sport of boxing, as it was the custom for a fighter to throw his hat into the boxing ring to signal his readiness to fight. 
Another interesting example in the domain of politics is shoo-in which is an American term meaning someone or something that seems sure to win. It originates from the sphere of football when before a big match, for example, supporters of each team are certain to argue about which team will win. Sometimes, though, one team appears much stronger than the other, and there seems to be no way it can lose. Everyone agrees that the stronger team which is the shoo-in will win.

The term shoo-in comes from the word "shoo" that is a word hundreds of years old and is associated with the meaning "to urge a person or an animal to move in a desired direction." Word experts say it was first used many years ago in horse racing, when dishonest riders agreed secretly to "throw the race," to hold back their horses, so that one chosen horse would win the race. The chosen riders would lose the race. But they would win money from secret bets on the chosen horse. The public soon learned about this dishonesty in races. They began to call the winner of such a race a "shoo-in". As years passed, the meaning changed and now "shoo-in" has nothing to do with cheating or illegal activity. It is now used to describe any athlete or competitor, certain to win. American runner Edwin Moses won more than a hundred races before the hurdles race in the 1984 Olympic games. Everyone said Moses was a shoo-in, that he was faster than any other competitor. They said he could not lose. And they were right. He won the gold medal.

The popularity of the word shoo-in established itself in the sphere of politics in the presidential election campaign of 1984. The study of the public opinion during the campaign showed much more support for the Republican president Ronald Reagan than for his opponent the Democrat Walter Mondale. So, Ronald Reagan was a "shoo-in" or in other words a hot favourite sure to win.

Another interesting idiom is fall guy just the opposite of shoo-in. This expression has made an easy jump from sport events to politics and everyday life. A fall guy is the person who is decided to be the loser or victim.

The first fall guys were men who wrestled for money. At the end of the last century, wrestling was a very popular sport in the United States. Wrestling matches were held not only in big cities but at country fairs and travelling shows.

As the sport became more popular, it gradually lost its sporting value. Many of the contests were "fixed," and the wrestlers knew before the match which of them would be the winner. 
The goal in wrestling is to hold your opponent's shoulders down against the floor. This is called a fall. Sometimes one of the wrestlers would be paid before the match to "take a fall." He agreed to be the loser for money i.e. the fall guy. Today, a fall guy in many different situations is somebody who is talked or tricked into taking the blame for someone else's crime or wrong doing. There are fall guys in many situations, people who publicly take the blame when something goes wrong.

Our observations show that not only sports terms and expressions have penetrated into our everyday speech, but also the names of sports champions. Thus, a case in point is the word combination the real McCoy. If a person tells you that something is "the real McCoy," he intends to inform that it is the real thing, not a copy or substitute. The idiomatic word combination "the real McCoy" is based on the name of the famous boxer and a former world champion Charles "Kid" McCoy, who once had an unpleasant incident.

McCoy was a peaceful man but one day when he was having a drink in a bar with a lady friend a man came up to them and without asking for permission began talking to the lady and offended her by pestering. McCoy had no other choice but mentioning he was Kid McCoy. However, this had no effect on the stranger who didn't believe his words. He even attempted a joke saying he was George Washington in that case and continued pestering the lady. McCoy could stand this no longer and had to hit the stranger with his fist. Although it was a very light touch, the man fell to the ground unconscious. However soon he came to himself and called out, "That was the real McCoy!" Hence the idiomatic meaning of the word combination "the real McCoy."

The intensive use of another common expression, game plan, outside the sports world, namely in economics, politics, social life, everyday speech among friends, etc., is meant to describe a detailed plan for dealing with changing situations. For example, the chairman of the US President's Council of Economic Advisers said that he would help to decide the "Washington game plan for economic policy" which thoroughly presented all the steps the government would take while accomplishing its aims and ideals in its economic policy.

The word combination game plan originates especially from football. Before any game, the coach will design a plan for his team to follow and in making the plan he needs to study the video and audio materials of the earlier games of the team. The study of those materials helps him to consider the strongest and 
weakest points of both teams. While making his game plan, he takes all those points into consideration and then instructs his players how to react to every possible move the opponents may take.

There is obviously nothing interesting and exciting in socks that people wear on their feet, but several interesting English expressions based on the word socks have so far been made. One such expression is pull up your socks meaning "try to do better, improve your performance." Imagine a basketball team near the end of an important game. The players are losing. They are so tired that even their socks look tired. The tops of their socks are falling down. The coach calls time out to talk to his team. "Take a breath", he tells them. "Get organized. If you pull up your socks, you can win this game." Thus, he is telling them they can win, if they start playing better. It is not a mere chance, then, that a magazine recently reported that a political leader told the members of his party they needed to "pull up their socks and get back in the game."

It should be mentioned that Americans' love for sport has helped to make many sports expressions part of everyday American speech. For example, the expression full court press, which also originated from the sphere of sports, means the strongest possible effort in order to get something done. A newspaper reported recently that the administration was planning a full court press to get its programme through Congress.

We have to agree that it is not easy to understand what it means just by looking at each of the components, for court, in this case, has nothing to do with trials or judges, and press does not mean newspapers. But a basketball player will be able to explain that it means a very forceful effort by one team to take control of the basketball game, for a basketball team scores by putting the ball through the basket at the opponent's end of the playing area or court. The team then usually runs quickly back to its own end of the court to defend its basket. It tries to keep the other team back from scoring. However, in a full court press a team does not retreat after it scores. Instead, it attacks or pressures its opponents with a very aggressive defense. Thus, when someone decides to make a strong extra effort to get something done, that person is making a full court press.

There are many baseball terms that are also used in everyday English. Here are several examples:

to retrieve a ball that has been hit - it appears in British and American variants of English in the sense of "deal with." 
to strike out - the baseball player has three strikes and is out for that time at bat, while the second meaning of the phrase is "to fail at doing something."

to keep pitching - the first meaning of this expression is to continue to throw the ball, but in everyday speech it is used as "to continue to work on something."

Popular familiarity with all kinds of sports shows that the most intensive use of sports idioms occurs in politics. Here are some additional examples:

sailing close to the wind (to take a risk: comes from sailing sport)

on the ropes (to be in a tough situation: a boxing term)

to score an own goal (to be mistaken: especially taken from football)

plain sailing (easy, without problems: comes from a sailing term)

kick off (to start something: a football term)

to be for the high jump (to be in a serious trouble: used in athletics)

steer clear off (to keep away from: it's an athletic term also used in running)

learning the ropes (to find out how to do something: used especially in learning boxing rules)

being thrown in at the deep end (to face a difficult situation without any preparation: is typical of a football game or boxing)

to give a free rein (to give someone freedom for action: used in horse racing)

boxed into a corner (to limit one's freedom to move or act: a boxing term)

below the belt (that was not fair: used in boxing)

to slow off the mark (be slow at starting something: used especially in car race)

neck and neck (equal position: in horse racing or in a contest, to fight with competitors for advantage or lead)

to move the goalposts (to change the rules to your own advantage: used in football or rugby)

to take the wind out of sail (to make someone feel less confident: used in sailing)

skating on thin ice (to do something risky or dangerous: from skating sport)

to do an end run (to go around the end of the opponent's defensive line: used especially in football and rugby)

carry the ball (to be responsible for a project in a business deal: used in all playing disciplines) 
to hold the line (to stay and not move: usually players try to stay in their position against the opponent's offensive attack in almost all playing disciplines).

The examples adduced above display the "hidden codes" of behavior in each culture, which can rarely be understood without a "code breaker" (Arens, Montague 1975); They reveal a fundamental tone characteristic of the voice of people's feelings and thoughts, help to capture the "soul" of a nation, as well as testify the capacity of sport to provide metaphoric interpretations of the objective reality into different spheres of activity, thus translating them into the popular consciousness of diverse cultures. Our observations allow us to conclude that idiomatic expressions originating from sports will continue to feature heavily in the English language for international communication.

\section{References:}

1. Aghayan, E. (1976) Ardi hayereni bacatrakan bararan. Yerevan: Hayastan hratarakchutyun.

2. Arens, W.; Montague, S. (1975) Professional Football: An American Symbol and Ritual in the American Dimension: Cultural Myths and Social Realities. Washington, New York: Alfred Publishing.

3. Beard, A. (1998) The Language of Sport. $1^{\text {st }}$ Edition. N.Y.: Psychology Press.

4. Edward, J. (1990) Understanding Cultural Differences. Yarmouth, ME: Intercultural Press.

5. (1962) Enciklopedicheskiy slovar' po fizicheskoi cul'ture i sportu. M.: Fizkul'tura i sport.

6. (1998) Football Dictionary. / Compiled and arranged by Th. Binder and M. Brasse. Zurich: published by FIFA.

7. Gavrilovets, A. (1979) English-Russian Dictionary of Sports Terms and Phrases. M.: Russian Language Publishers.

8. Hymes, D. (1974) Foundations in Sociolinguistics: An Ethnographic Approach. Philadelphia: University of Pennsylvania Press.

9. (1993) Oxford Dictionary of Phrasal Verbs. Oxford: OUP.

10.(1997) Oxford Dictionary of English Idioms. Oxford: OUP.

11.(2005) Oxford Dictionary of Foreign Words and Phrases. Oxford: OUP.

12.Palmatier, R.; Ray, H. (1989) Sports Talk: A Dictionary of Sports Metaphors. New York: Greenwood Publishers. 
13.Saphonova, V. (1991) Sotsiokulturniy podkhod k obucheniu inostrannomy yaziku. M.: Visshaya shkola.

14.Tomakhin, G. (1999) Lingvostranovedcheskiy slovar'. M.: Rus.yaz.

15.Vereschagin, Y.; Kostomarov V. (1990) Yazyk i kul'tura. M.: Rus.yaz.

16.(1989) Webster's Encyclopedic Dictionary of the English Language. New York: Gramercy Book.

17.Zarokhovich, L. (2002) Anglo-ruskiy i rusko-angliyskiy slovar' futbolnykh terminov. M.: Izdatel'stvo AST.

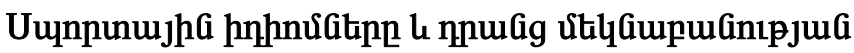

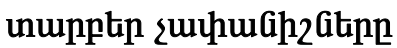

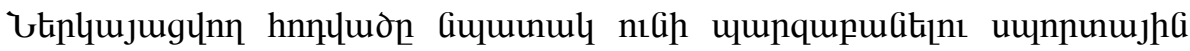

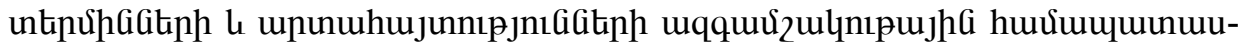

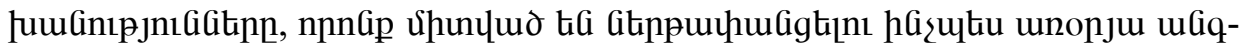

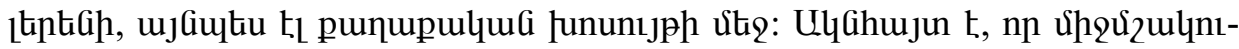

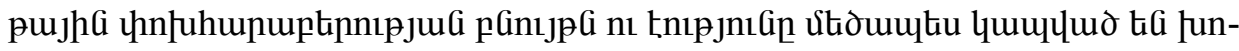

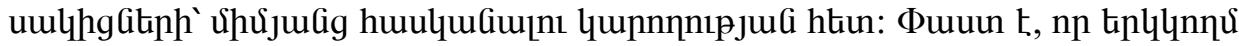

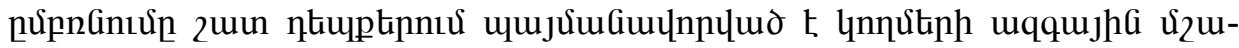

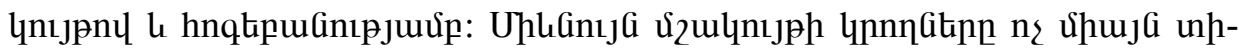

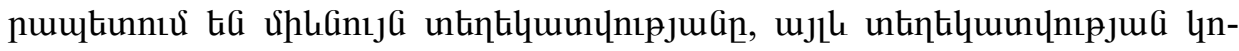

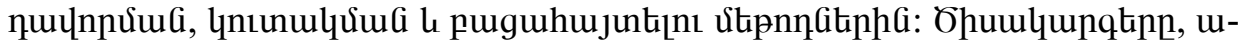

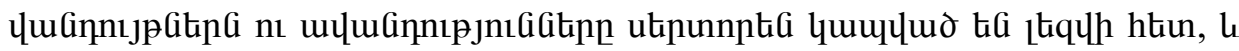

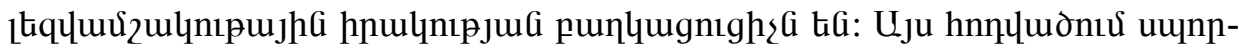

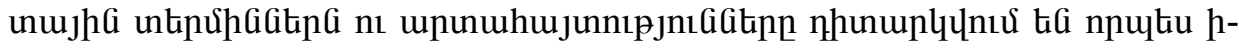

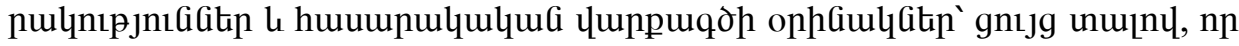

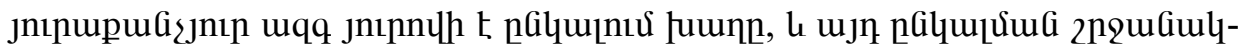

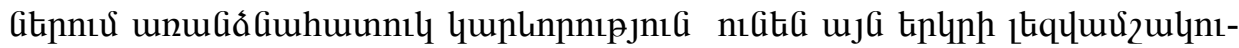
pujhG uцuGinnıjpGitnn, npuntinhg wja utipntu $\mathrm{t}:$

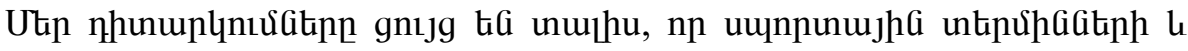
ununuhujunnıpjntigitph jujG lhpunntpjnı

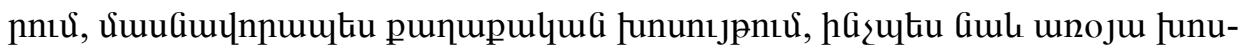

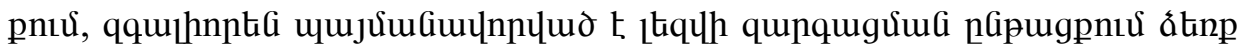

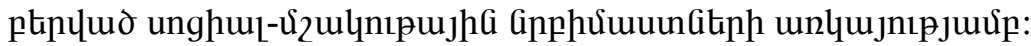

